\title{
Uji Validitas Konstruk Pembentukan Karakter Moral Remaja
}

\author{
Layyinah $^{1}$, Adiyo Roebianto ${ }^{2}$ \\ Fakultas Psikologi, UIN Syarif Hidayatullah Jakarta, Indonesia ${ }^{1}$ \\ Fakultas Psikologi, Universitas Mercu Buana Jakarta, Indonesia ${ }^{2}$ \\ layyinah@uinjkt.ac.id
}

\begin{abstract}
Moral is an important thing in a person's character. However, today Indonesian society has experienced many moral setbacks, especially among adolescents. This causes a moral crisis in adolescents. Although the crisis was realized, it was never known empirically about the moral crisis that occurred. This study intends to test the construct validity of the moral character instrument by means of a confirmatory factor analysis approach. The author's moral character instrument is compiled using a Likert model. Participants in this study were junior high and high school students in two different schools with a total of $153(n=153)$. The results of the CFA analysis show that the multidimensional model on moral instruments is declared fit with the data. However, there are several notes regarding the considerable number of invalid statement items on moral instruments.
\end{abstract}

Keywords: moral, moral character instruments, confirmatory factor analysis.

\begin{abstract}
Abstrak
Moral adalah hal yang penting dalam karakter seseorang. Namun, dewasa ini masyarakat Indonesia telah mengalami banyak kemunduran pada segi moral, terutama pada remaja. Hal ini menyebabkan krisis moral pada diri remaja. Meskipun disadari terjadinya krisis, tetapi tidak pernah diketahui secara empiris mengenai krisis moral yang terjadi. Penelitian ini bermaksud untuk menguji validitas konstruk instrumen karakter moral melalui pendekatan analisis faktor konfirmatorik (Confirmatory Factor Analysis). Instrumen karakter moral disusun oleh penulis dengan menggunakan model Likert. Partisipan dalam penelitian ini adalah siswa SMA di dua sekolah berbeda dengan jumlah sebesar $153(\mathrm{n}=153)$. Hasil analisis CFA menunjukkan bahwa model multidimensional pada instrumen moral dinyatakan fit dengan data. Kendati demikian, terdapat beberapa catatan mengenai cukup banyaknya item pernyataan yang tidak valid pada instrumen karakter moral.
\end{abstract}

Kata Kunci: moral, instrumen karakter moral, analisis faktor konfirmatorik. 


\section{Pendahuluan}

Arus globalisasi telah memberikan banyak perubahan terhadap seluruh kehidupan masyarakat Indonesia. Dewasa ini masyarakat Indonesia telah mengalami krisis moral terutama pada segi etika, sopan santun, pergaulan, gaya hidup, kepedulian sesama masyarakat yang semakin tidak acuh, dan lain sebagainya. Dampak negatif lainnya yang sangat memprihatinkan adalah perubahan yang cenderung mengarah pada krisis moral dan akhlak masyarakat Indonesia terutama pada remaja, seperti fenomena pergaulan bebas (free life style), tayangan televisi yang berisi film-film tentang pornografi dan pornoaksi yang mengakibatkan banyak anak sekolah hamil di luar nikah. Selain itu, terjadi pelecehan seksual sehingga menimbulkan sejumlah permasalahan kompleks salah satunya krisis moral yang melanda negeri ini. Penelitian ini bertujuan untuk menguji apakah dimensi yang ada dalam pembentukan karakter moral beserta item-itemnya mewakili pengukuran terhadap pembentukan karakter moral berdasarkan teori Lickona.

Aristoteles (dalam Lickona, 2012) mendefenisikan karakter yang baik dalam kehidupan yaitu dengan melakukan tindakan-tindakan yang benar yang berhubungan dengan diri dan orang lain. Menurut Lickona (2012) karakter yang baik terdiri dari mengetahui yang baik, menginginkan hal yang baik, dan melakukan hal yang baik. Hal itu tercermin baik dalam kebiasaan, cara berpikir, kebiasaan dalam hati, dan kebiasaan dalam tindakan. Karakter didefinisikan sebagai sekumpulan trait positif yang terefleksi dalam pikiran, perasaan, dan perilaku (Park \& Peterson, 2006). Karakter merupakan perwujudan dari moral yang tertanam dalam diri individu.

Menurut Holmgren (2004), individu yang memiliki karakter yang kuat mampu bersikap rasional dan tidak mudah terombang-ambing oleh keyakinan yang salah tentang nilai sesuatu yang ada di luar dirinya. Lebih lanjut diungkapkan bahwa karakter kuat yang sesungguhnya tidak hanya menyangkut kepedulian eksternal, tetapi kepedulian yang secara terus-menerus diasah dan diregulasi oleh kebijakan. Dalam kebijakan yang matang terkandung dua komponen yakni kemampuan mengenali kesalahan dari perspektif moral sekarang, dan adanya pemahaman moral yang baru, atau pengenalan apa yang sebenarnya penting, bernilai, atau berharga dalam kehidupan.

Menurut (Cohen \& Morse, 2014), karakter moral dapat dikonseptualisasikan sebagai watak individu untuk berpikir, merasakan, dan berperilaku etis. Seseorang yang bermoral berarti mampu berperilaku sesuai dengan prinsip atau standar perilaku dalam masyarakat. Koehler dan Royer (2001) menjelaskan ciri-ciri karakter adalah sebagai berikut:

1. Memiliki kepedulian terhadap orang lain dan terbuka terhadap pengalaman dari luar.

2. Secara konsisten mampu mengelola emosi.

3. Memiliki kesadaran terhadap tanggung jawab sosial dan menerimanya tanpa pamrih.

4. Melakukan tindakan yang benar meskipun tidak ada orang lain yang melihat.

5. Memiliki kekuatan dari dalam untuk mengupayakan keharmonisan dengan lingkungan sekitar.

6. Mengembangkan standar pribadi yang tepat dan berperilaku yang konsisten dengan standar tersebut.

Nucci \& Narvaes (2008) menyatakan bahwa moral merupakan faktor determinan atau penentu pembentukan karakter seseorang. Oleh karena itu, indikator manusia yang berkarakter moral adalah:

1. Personal improvement, yaitu individu yang mempunyai kepribadian yang teguh terhadap aturan yang diinternalisasi dalam dirinya. Artinya ia tidak mudah goyah dengan pengaruh lingkungan sosial yang dianggapnya tidak sesuai dengan aturan yang diinternalisasi tersebut. Ciri kepribadian tersebut secara kontemporer diistilahkan sebagai integritas. Individu yang mempunyai integritas yang tinggi terhadap nilai dan aturan yang dia junjung tidak akan melakukan tindakan amoral. Sebagai contoh, 
individu yang menjunjung tinggi nilai agamanya tidak akan terpengaruh oleh lingkungan sosial untuk menyontek, manipulasi, dan korupsi.

2. Social skill, yaitu mempunyai kepekaan sosial yang tinggi sehingga mampu mengutamakan kepentingan orang lain. Hal ini ditunjukkan dengan hubungan sosialnya yang harmonis. Setiap nilai atau aturan universal tentunya akan mengarahkan manusia untuk menjaga hubungan baik dengan orang lain. Contohnya, individu yang religius pasti akan berbuat baik untuk orang lain atau mengutamakan kepentingan umat.

3. Comprehensive problem solving, yaitu sejauh mana individu dapat mengatasi konflik dilematis antara pengaruh lingkungan sosial yang tidak sesuai dengan nilai atau aturan dengan integritas pribadinya terhadap nilai atau aturan tersebut. Dalam arti, individu mempunyai pemahaman terhadap tindakan orang lain (perspektif lain) yang menyimpang tetapi individu tersebut tetap mendasarkan keputusan/sikap/tindakannya kepada nilai atau aturan yang telah diinternalisasikan dalam dirinya. Sebagai contoh, seorang murid yang tidak mau mengikuti teman-temannya menyontek saat tidak diawasi oleh guru karena ia tetap menjunjung tinggi nilai atau aturan yang berlaku (kejujuran). Meskipun sebenarnya ia mampu memahami penyebab perilaku teman-temannya yang menyontek. Keluwesan dalam berpikir dan memahami inilah dibutuhkan untuk menilai suatu perbuatan tersebut benar atau salah.

Menurut Lickona (2012), karakter berkaitan dengan beberapa konsep yaitu berkaitan dengan konsep moral (moral knowing), sikap moral (moral feeling), dan perilaku moral (moral behavior). Ryan dan Lickona (1992) mengungkapkan bahwa dalam karakter manusia terdapat tiga komponen, yaitu:

Pertama, pengetahuan moral (moral knowing). Dalam komponen pengetahuan moral tercakup penalaran moral dan strategi kognitif yang digunakan untuk mengambil keputusan secara sistematis. Melalui komponen ini individu dapat membayangkan konsekuensi yang akan terjadi di kemudian hari dari keputusan yang diambil dan sikap bagaimana menghadapi konsekuensi tersebut. Pengetahuan moral terdiri dari:

1. Kesadaran moral: kemampuan untuk melihat bahwa situasi yang kita hadapi melibatkan permasalahan moral dan memerlukan penilaian moral contohnya melanggar aturan yang telah disepakati. Dalam kesadaran moral menggunakan pemikiran mereka untuk melihat suatu situasi yang memerlukan penilaian moral dan kemudian untuk memikirkan dengan cermat tentang apa yang dimaksud dengan arah tindakan yang benar. Serta memahami informasi dari permasalahan yang ada.

2. Penilaian nilai moral: memahami bagaimana caranya menerapkan nilai moral dalam berbagai macam situasi.

3. Penentuan perspektif: kemampuan untuk mengambil sudut pandang orang lain, melihat situasi sebagaimana adanya, membayangkan bagaimana mereka akan berpikir, bereaksi, dan merasakan masalah yang ada.

4. Pemikiran moral: pemikiran moral melibatkan pemahaman apa yang dimaksud dengan moral. Pemikiran moral yang baik dan apa yang tidak dianggap sebagai pemikiran moral yang baik karena melakukan suatu hal.

5. Pengambilan keputusan: mampu memikirkan cara seseorang bertindak melalui permasalahan moral. Keputusan yang harus diambil dalam dilema moral.

6. Pengetahuan pribadi: kemampuan untuk mengevaluasi perilaku diri kita sendiri secara kritis. 
Kedua, perasaan moral (moral affect), yang mencakup identitas moral, ketertarikan terhadap kebaikan, komitmen, hati nurani, dan empati yang semuanya merupakan sisi afektif dari moral pada diri individu. Perasaan moral terdiri dari:

1. Hati nurani: mengetahui apa yang benar dan merasa berkewajiban untuk melakukan apa yang benar.

2. Harga diri: keyakinan yakin akan kemampuan dalam hal tanggung jawab, kejujuran, dan kebaikan.

3. Empati: empati merupakan identifikasi dengan pengalaman yang terjadi seolah-olah terjadi dalam keadaan orang lain. Kemampuan untuk keluar dari diri kita sendiri dan masuk ke dalam orang lain.

4. Mencintai hal yang baik: kemampuan mencintai hal yang baik dan membenci hal yang buruk.

5. Kendali diri: kemampuan untuk mengendalikan diri. Kendali diri diperlukan untuk menahan diri agar tidak memanjakan diri kita sendiri.

6. Kerendahan hati: kemampuan untuk tidak merendahkan orang lain. Kerendahan hati merupakan sisi afektif pengetahuan diri. Hal ini merupakan keterbukaan yang sejati terhadap kebenaran dan keinginan untuk bertindak guna memperbaiki kegagalan.

Ketiga, tindakan moral (moral action) yang memiliki tiga komponen yaitu kehedak, kompetensi, dan kebiasaan.

1. Kompetensi: memiliki kemampuan untuk mengubah penilaian dari perasaan moral ke dalam tindakan moral untuk memecahkan suatu konflik yang adil. Misalnya, kita memerlukan keahlian praktis mendengarkan, menyampaikan sudut pandang kita tanpa mencemarkan nama baik orang lain, dan mengusahakan solusi yang dapat diterima semua pihak.

2. Keinginan: bisa memilih yang benar dalam suatu situasi moral keinginan berada pada inti dorongan moral. Pilihan yang benar dalam suatu situasi moral biasanya merupakan pilihan yang sulit. Menjadi orang baik sering kali memerlukan tindakan keinginan yang baik, suatu pergerakan energi moral untuk melakukan apa yang harus kita pikir kita harus lakukan. Diperlukan keinginan untuk menjaga emosi di bawah kendali pemikiran. Diperlukan keinginan untuk melihat dan berpikir seluruh dimensi moral dalam suatu situasi. Diperlukan keinginan untuk menolak godaan, menentang tekanan teman sebaya, dan melawan gelombang. Keinginan berada pada inti dorongan moral.

3. Kebiasaan: melakukan kebiasaan yang baik. Dalam situasi yang besar, pelaksanaan tindakan moral memperoleh manfaat dari kebiasaan. Menurut Wiiliam Bennet "bertindak sebenarnya, dengan loyal, dengan berani, dengan baik, dan dengan adil tanpa merasa amat tertekan oleh arah tindakan sebaliknya". Sering kali orang-orang ini melakukan hal yang baik karena dorongan kebiasaan.

Berdasarkan tiga komponen ini dapat dinyatakan bahwa karakter yang baik didukung oleh pengetahuan tentang kebaikan, keinginan untuk berbuat baik dan melakukan perbuatan baik. Dalam penelitian ini teori yang digunakan adalah Teori Rian dan Lickona (1992). Adapun pertanyaan dalam penelitian ini adalah apakah item-item yang terdapat dalam dimensi pembentukan karakter moral remaja mengukur dimensi pengetahuan moral, perasaan moral dan tindakan atau prilaku moral?

\section{Metode}

Alat ukur karakter moral yang digunakan dalam penelitian ini berdasarkan teori Ryan dan Lickona (1992) yang terdiri dari tiga dimensi, yaitu: pengetahuan moral, perasaan moral, dan tindakan moral. Peneliti membuat butir pertanyaan yang dikembangkan dari teori Ryan dan Lickona (1992) dengan 46 butir pernyataan. Terdiri dari dimensi pengetahuan moral terdiri dari 10 item, perasaan moral terdiri dari 24 item, dan terakhir tindakan moral terdiri dari 12 item. Semua item tersebut disusun dalam bentuk 
favorable. Setiap pernyataan memiliki empat format respons jawaban, yaitu: sangat sesuai, sesuai, tidak sesuai, dan sangat tidak sesuai.

Subjek pada penelitian ini yaitu siswa Sekolah Menengah Atas dan Madrasah Aliyah di Jakarta yang terdiri dari 153 siswa. Teknik pengambilan sampel yang digunakan adalah non probability purpossive sampling dari dua Sekolah Mengengah Atas, yaitu: SMAN 74 Jakarta Selatan dan MAN 5 Jakarta Utara, dengan menggunakan Analisa data CFA (Confirmatory Factor Analysis).

\section{Hasil dan Pembahasan}

\section{Uji Validitas}

Dalam penelitian ini, dilakukan analisis faktor konfirmatorik (Confirmatory Factor Analysis/CFA) dari 46 item yang mengukur pembentukan karakter moral pada remaja. Peneliti melakukan analisis CFA untuk mencari pola dari multidimensionalitas item pembentukan karakter moral sehingga bisa diperoleh kelompok item yang mengukur konstruk pembentukan karakter moral pada remaja. Secara ringkas, penulis kutip dari artikel Umar dan Nisa (2020) mengenai logika CFA yaitu (secara detail dapat dilihat pada sumber asli):

1. Menetapkan model pengukuran yang akan diuji. Dalam hal ini menentukan item dan banyaknya dimensi/faktor yang akan diuji. Pada penelitian ini penulis memiliki 48 item, tiga dimensi (pengetahuan moral, perasaan moral, dan tindakan moral) dan satu faktor umum (karakter moral).

2. Dikarenakan dalam CFA membuktikan apakah berkorelasinya antaritem disebabkan oleh suatu faktor (teori) maka dapat dibuat persamaannya menjadi $\Sigma=\Lambda \Lambda^{\prime}+\Theta$ dimana $\sum$ adalah matriks korelasi antaritem berdasarkan teori. Dengan kata lain, matriks $\sum$ adalah matriks yang berisi nilai prediksi atau nilai yang seharusnya.

3. Selain memiliki matriks korelasi berdasarkan teori, tetapi juga dalam CFA memiliki matriks korelasi berdasarkan data empiris, yang dalam hal ini disimbolkan dengan S. Isi dari matriks korelasi dari data yaitu korelasi antaritem yang datanya diperoleh dari data lapangan.

4. Dikarenakan ada dua matriks tersebut $\left(\sum \& S\right)$, maka keduanya dapat dibandingkan apakah keduanya berbeda signifikan dari nol $\left(\sum-\mathrm{S}=0\right)$. Tentu dalam menilai perbedaannya menggunakan beberapa kriteria model fit, di antaranya Chi-Square, RMSEA, TLI, CFI, dsb.

5. Jika selisih antara kedua matriks tersebut tidak signifikan, maka hipotesis $\sum-\mathrm{S}=0$ dinyatakan tidak ditolak, artinya model teori dinyatakan fit dengan data. Tetapi sebaliknya, jika perbedaan kedua matriks tersebut signifikan, maka model teori dinyatakan tidak fit dengan data.

6. Jika model fit (valid) maka selanjutnya adalah menguji signifikansi tiap loading factor pada item. Jika koefisien tersebut signifikan, maka artinya item tersebut berkontribusi signifikan dalam mengukur konstruk yang diniatkan dan sebaliknya.

7. Terakhir, jika model teori tidak fit dengan data, maka dapat dilakukan modifikasi pada model pengukuran, misalnya dengan cara membebaskan korelasi kesalahan pengukuran antaritem. Hal tersebut dapat dilakukan hingga model dinyatakan fit (valid).

Adapun analisis CFA tersebut dilakukan pada dua level, yaitu level pertama analisis CFA pada tiap dimensi. Kemudian, analisis CFA dilakukan secara bersama-sama mulai dari item, dimensi, hingga ke faktor karakter moral. Adapun analisis CFA dilakukan dengan menggunakan software LISREL 8 (Joreskog \& Sorbom, 2004).

Dengan demikian, ada dua proses analisis, yaitu pertama analisis CFA pada tahapan dimensi, dimana dilakukan sebanyak tiga kali. Kemudian, item yang dinyatakan valid dari analisis tahap ke-1, maka 
dilanjutkan dengan analisis tahap ke-2, yaitu CFA hierarchical model atau second order factor. Pada tahapan yang ke-2 ini, penulis membuat model pengukuran yaitu ada satu faktor umum yang menyebabkan berkorelasinya (mempengaruhi) tiga dimensi, kemudian tiap dimensi tersebut memiliki masing-masing item yang mengukurnya.

\section{Uji Validitas Konstruk Pembentukan Karakter pada Remaja}

\section{a. Faktor Pengetahuan Moral}

Berdasarkan hasil analisis awal CFA terhadap model unidimensional pengetahuan moral (faktor 1) didapati nilai Chi-Square sebesar 467,36, $\mathrm{df}=35(\mathrm{p}<0,05)$; $\mathrm{RMSEA}=0,285$. Hasil ini didapati model unidimensionalnya tidak fit. Kemudian selanjutnya penulis melakukan perubahan pada model pengukuran unidimensional dengan cara membebaskan korelasi kesalahan pengukuran antaritem. Hingga didapatkan model fit dengan nilai Chi-Square sebesar 21,75, $\mathrm{df}=17(\mathrm{p}>0,05)$; RSEA $=0,045$. Adapun gambarnya dapat dilihat sebagai berikut.

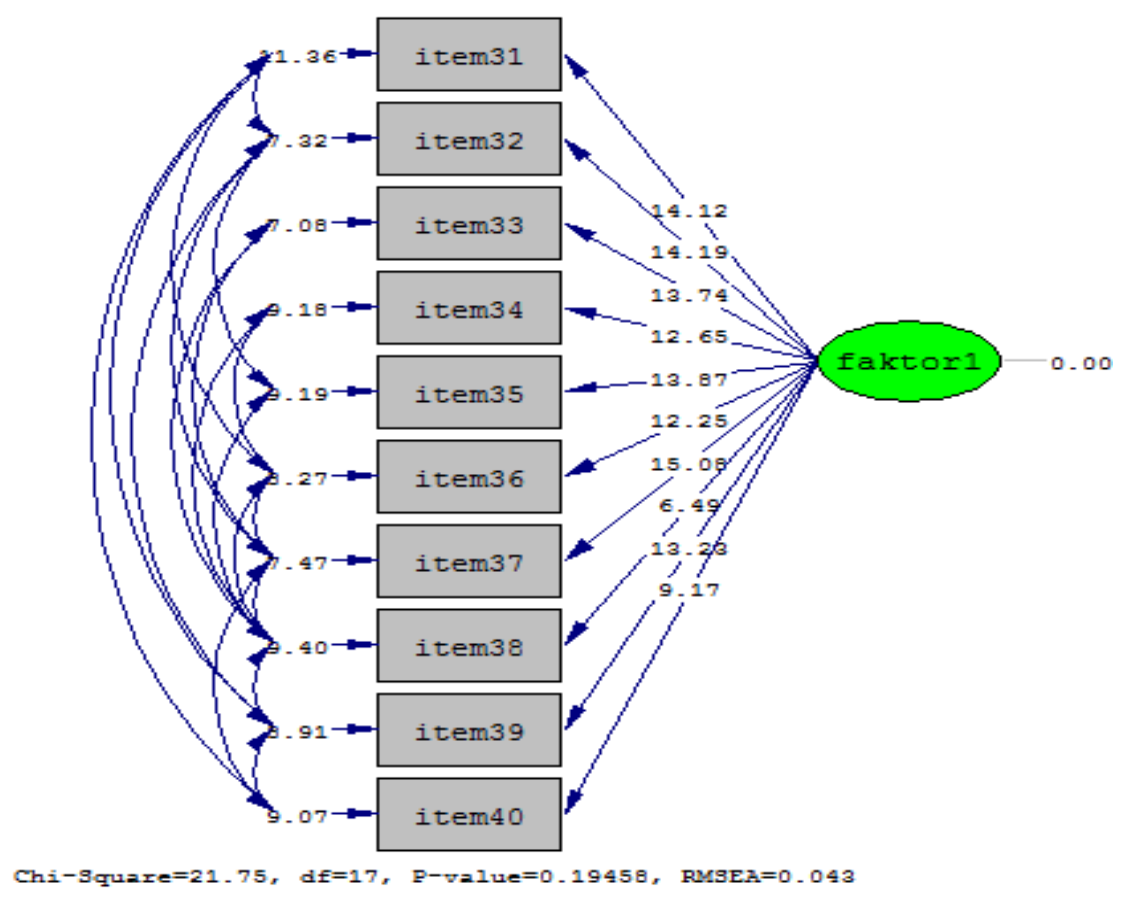

Gambar 1. Hasil CFA Dimensi Pengetahuan Moral

Dari Gambar 1, terlihat bahwa terdapat beberapa kesalahan pengukuran yang saling berkorelasi, Adapun laporannya penulis jadikan satu dengan hasil uji signifikansi factor loading. Menurut Umar \& Nisa (2020) suatu factor loading dinyatakan signifikan apabila nilai $\mathrm{t}(\mathrm{t}$-value) pada item tersebut lebih dari 1,96 ( $\mathrm{t}$ $>1,96)$. Hasilnya dapat dilihat pada tabel berikut ini.

Tabel 1. Standardized Factor Loading Dimensi Pengetahuan Moral

\begin{tabular}{ccccc}
\hline No. Item & Lambda & Std. Error & T-Value & $\begin{array}{c}\text { Jumlah Korelasi } \\
\text { Kesalahan Pengukuran }\end{array}$ \\
\hline $\mathbf{3 1}$ & 0,89 & 0,06 & 14,12 & 4 \\
$\mathbf{3 2}$ & 0,90 & 0,06 & 14,19 & 4 \\
$\mathbf{3 3}$ & 0,88 & 0,06 & 13,74 & 2 \\
$\mathbf{3 4}$ & 0,83 & 0,06 & 12,65 & 2 \\
$\mathbf{3 5}$ & 0,88 & 0,06 & 13,87 & 2 \\
$\mathbf{3 6}$ & 0,82 & 0,07 & 12,25 & 4 \\
\hline
\end{tabular}




\begin{tabular}{lllcl}
\hline $\mathbf{3 7}$ & 0,92 & 0,06 & 15,08 & 5 \\
$\mathbf{3 8}$ & 0,50 & 0,08 & 6,49 & 6 \\
$\mathbf{3 9}$ & 0,86 & 0,06 & 13,23 & 4 \\
$\mathbf{4 0}$ & 0,66 & 0,07 & 9,17 & 3 \\
\hline
\end{tabular}

Berdasarkan Tabel 1, dapat dilihat bahwa semua item memiliki nilait di atas 1,96 ( $p<0,05)$, yang artinya berdasarkan uji signifikansi koefisien regresi tiap item dinyatakan valid atau berkontribusi signifikan terhadap mengukur aspek pengetahuan moral. Namun demikian, terdapat item yang kesalahan pengukurannya justru berkorelasi cukup banyak dengan item lainnya. Hal ini mengindikasikan bahwa sejatinya item-item tersebut tidak unidimensional, seperti item 31, 32, 36, 37, 38 dan 39. Tentu hal ini berdampak buruk terhadap model fit dimensi pengetahuan moral. Oleh karenanya, penulis akan mendrop item-item tersebut ketika melakukan analisis CFA tahap ke-2.

\section{b. Faktor Perasaan Moral}

Berdasarkan hasil analisis awal CFA terhadap model unidimensional perasaan moral (faktor 2) didapati nilai Chi-Square sebesar 966,93, $\mathrm{df}=252(\mathrm{p}<0,05)$; $\mathrm{RMSEA}=0,137$. Dengan demikian, dari hasil awal didapati model unidimensionalnya tidak fit. Kemudian penulis melakukan perubahan pada model pengukuran unidimensional dengan cara membebaskan korelasi kesalahan pengukuran antaritem. Hingga didapatkan model fit dengan nilai Chi-Square sebesar 195,51, $\mathrm{df}=166(\mathrm{p}>0,05)$; RMSEA $=0,034$. Adapun gambarnya dapat dilihat sebagai berikut: 


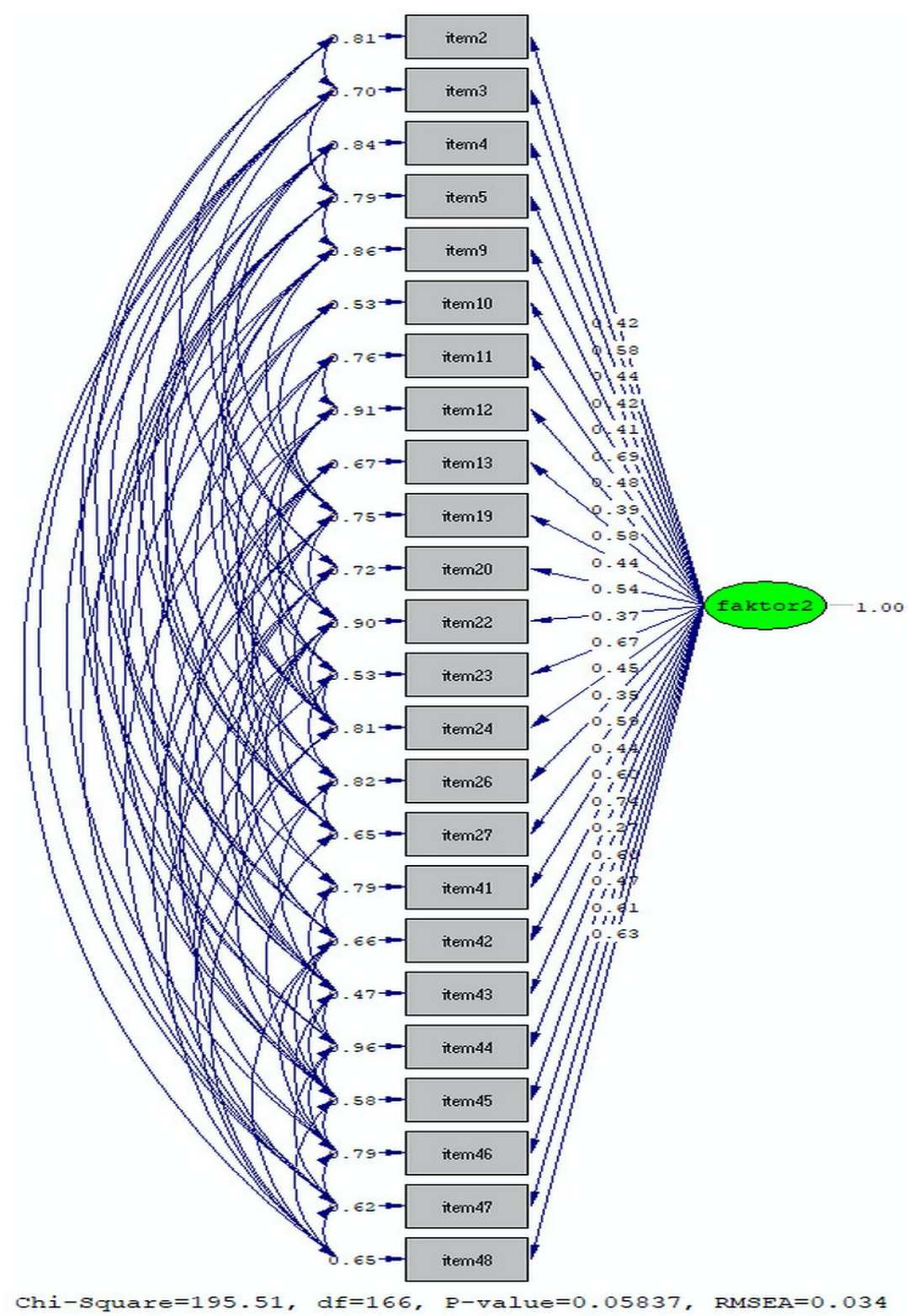

Gambar 2. Hasil CFA Dimensi Perasaan Moral

Dari Gambar 2, terlihat bahwa terdapat banyak kesalahan pengukuran yang saling berkorelasi, Adapun laporannya penulis jadikan satu dengan hasil uji signifikansi factor loading. Hasilnya dapat dilihat pada tabel berikut ini.

Tabel 2. Standardized Factor Loading Dimensi Perasaan Moral

\begin{tabular}{ccccc}
\hline No. Item & Lambda & Std. Error & T-Value & $\begin{array}{c}\text { Jumlah Korelasi } \\
\text { Kesalahan } \\
\text { Pengukuran }\end{array}$ \\
\hline $\mathbf{2}$ & 0,42 & 0,08 & 5,42 & 4 \\
$\mathbf{3}$ & 0,58 & 0,08 & 7,63 & 8 \\
$\mathbf{4}$ & 0,44 & 0,08 & 5,56 & 6 \\
$\mathbf{5}$ & 0,42 & 0,08 & 5,29 & 9 \\
$\mathbf{9}$ & 0,41 & 0,08 & 5,21 & 6 \\
$\mathbf{1 0}$ & 0,69 & 0,07 & 9,38 & 4 \\
$\mathbf{1 1}$ & 0,48 & 0,08 & 6,36 & 4 \\
\hline
\end{tabular}




\begin{tabular}{lcccc}
\hline $\mathbf{1 2}$ & 0,39 & 0,08 & 4,91 & 5 \\
$\mathbf{1 3}$ & 0,58 & 0,08 & 7,44 & 5 \\
$\mathbf{1 9}$ & 0,44 & 0,08 & 5,72 & 9 \\
$\mathbf{2 0}$ & 0,54 & 0,08 & 7,07 & 6 \\
$\mathbf{2 2}$ & 0,37 & 0,08 & 4,51 & 9 \\
$\mathbf{2 3}$ & 0,67 & 0,08 & 9,57 & 6 \\
$\mathbf{2 4}$ & 0,45 & 0,08 & 5,65 & 9 \\
$\mathbf{2 6}$ & 0,35 & 0,08 & 4,54 & 7 \\
$\mathbf{2 7}$ & 0,59 & 0,08 & 7,69 & 9 \\
$\mathbf{4 1}$ & 0,44 & 0,08 & 5,68 & 4 \\
$\mathbf{4 2}$ & 0,60 & 0,08 & 7,77 & 10 \\
$\mathbf{4 3}$ & 0,74 & 0,07 & 10,10 & 10 \\
$\mathbf{4 4}$ & 0,27 & 0,09 & 3,13 & 8 \\
$\mathbf{4 5}$ & 0,60 & 0,08 & 7,98 & 7 \\
$\mathbf{4 6}$ & 0,47 & 0,08 & 5,72 & 8 \\
$\mathbf{4 7}$ & 0,61 & 0,07 & 8,31 & 7 \\
$\mathbf{4 8}$ & 0,63 & 0,08 & 8,26 & \\
\hline
\end{tabular}

Berdasarkan Tabel 2, terlihat bahwa seluruh item memiliki koefisien regresi yang signifikan $(t>1,96)$. Hal ini berarti secara kontribusi, item-item tersebut berkontribusi signifikan dalam mengukur konstruk penalaran moral. Namun demikian, secara unidimensionalitas, masih ada beberapa item yang korelasi kesalahan pengukurannya cukup banyak lebih dari 5 kali, yaitu seperti item 3, 4, 5, 9, 19, 20, 22, 23, 24, $26,27,42,43,44,45,46,47$, dan 48. Dikarenakan terlalu banyak korelasi kesalahan pengukuran tersebut yang menyebabkan model unidimensional tidak fit, maka item-item tersebut didrop ketika menghitung CFA pada proses second order.

\section{c. Tindakan Moral}

Berdasarkan hasil analisis awal CFA terhadap model unidimensional tindakan moral (faktor 3) didapati nilai Chi-Square sebesar 268,38, $\mathrm{df}=54(\mathrm{p}<0,05)$; RMSEA $=0,162$. Dengan demikian, dari hasil awal didapati model unidimensionalnya tidak fit. Kemudian selanjutnya penulis melakukan perubahan pada model pengukuran unidimensional dengan cara membebaskan korelasi kesalahan pengukuran antaritem, sehingga didapatkan model fit dengan nilai Chi-Square sebesar 48,38, $\mathrm{df}=37(\mathrm{p}>0,05)$; $\mathrm{RMSEA}=$ 0,045 . Adapun gambarnya dapat dilihat sebagai berikut. 


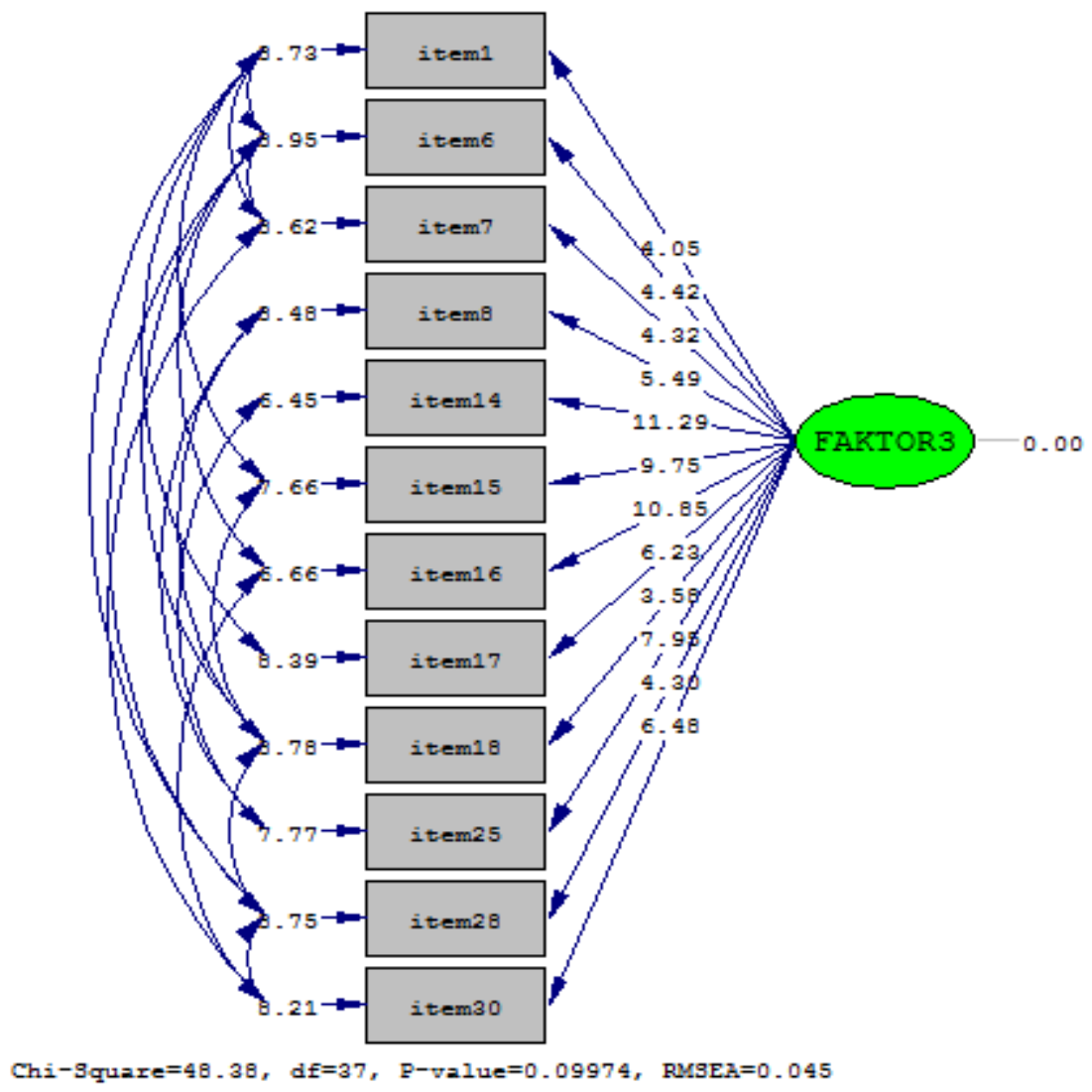

Gambar 3. Hasil CFA Dimensi Tindakan Moral

Dari Gambar 3, terlihat bahwa meskipun didapati model yang fit ( $\mathrm{p}>, 05)$, namun kenyataannya masih terdapat item yang kesalahan pengukurannya berkorelasi satu sama lain. Hal ini mengakibatkan item tersebut menjadi tidak unidimensional. Oleh karena itu, penulis akan mendrop item yang memiliki korelasi kesalahan pengukuran terlalu banyak. Adapun rangkuman dari kondisi tersebut ditulis pada tabel berikut ini.

Tabel 3. Standardized Factor Loading Dimensi Tindakan Moral

\begin{tabular}{ccccc}
\hline No. Item & Lambda & Std. Error & T-Value & $\begin{array}{c}\text { Jumlah Korelasi } \\
\text { Kesalahan } \\
\text { Pengukuran }\end{array}$ \\
\hline $\mathbf{1}$ & 0,34 & 0,08 & 4,05 & 5 \\
$\mathbf{6}$ & 0,39 & 0,09 & 4,42 & 5 \\
$\mathbf{7}$ & 0,36 & 0,08 & 4,32 & 5 \\
$\mathbf{8}$ & 0,45 & 0,08 & 5,49 & 2 \\
$\mathbf{1 4}$ & 0,80 & 0,07 & 11,29 & 1 \\
$\mathbf{1 5}$ & 0,71 & 0,07 & 9,75 & 2 \\
$\mathbf{1 6}$ & 0,78 & 0,07 & 9,75 & 2 \\
$\mathbf{1 7}$ & 0,50 & 0,08 & 6,23 & 1 \\
$\mathbf{1 8}$ & 0,30 & 0,08 & 3,58 & 4 \\
$\mathbf{2 5}$ & 0,63 & 0,08 & 7,95 & 2 \\
$\mathbf{2 8}$ & 0,36 & 0,08 & 4,30 & 4 \\
$\mathbf{3 0}$ & 0,52 & 0,08 & 6,48 & 3 \\
\hline
\end{tabular}


Berdasarkan Tabel 3, semua item memiliki nilai t lebih dari 1,96, yang artinya item-item tersebut memiliki kontribusi yang signifikan dalam mengukur konstruk tindakan moral. Kendati demikian, terdapat beberapa item yang korelasi kesalahan pengukurannya cukup banyak, seperti item 1, 6, 7, 18 dan 28. Maka dari itu, item yang demikian akan didrop pada saat menghitung second order CFA.

\section{Second Order CFA}

Pada bagian ini penulis menguji model pengukuran secara lebih komprehensif, dimana ada tiga level; yaitu level pertama adalah item/pernyataan, kemudian level kedua adalah dimensi, dan yang ketiga adalah general factor, dalam hal ini karakter moral. Dengan demikian, berdasarkan analisis tahap pertama, dimensi pengetahuan moral akan ada empat item, dimensi penalaran moral memiliki enam item, dan terakhir dimensi tindakan moral memiliki tujuh item.

Hasil awal CFA didapati nilai Chi-Square sebesar 202,619, df $=116(p<0,05)$; RMSEA = 0,072. Hal ini menunjukkan model awal second order dinyatakan tidak fit. Oleh karena itu, penulis melakukan modifikasi pada model dengan cara membebaskan korelasi kesalahan pengukuran pada item, sehingga diperoleh hasil yang fit sebagai berikut.

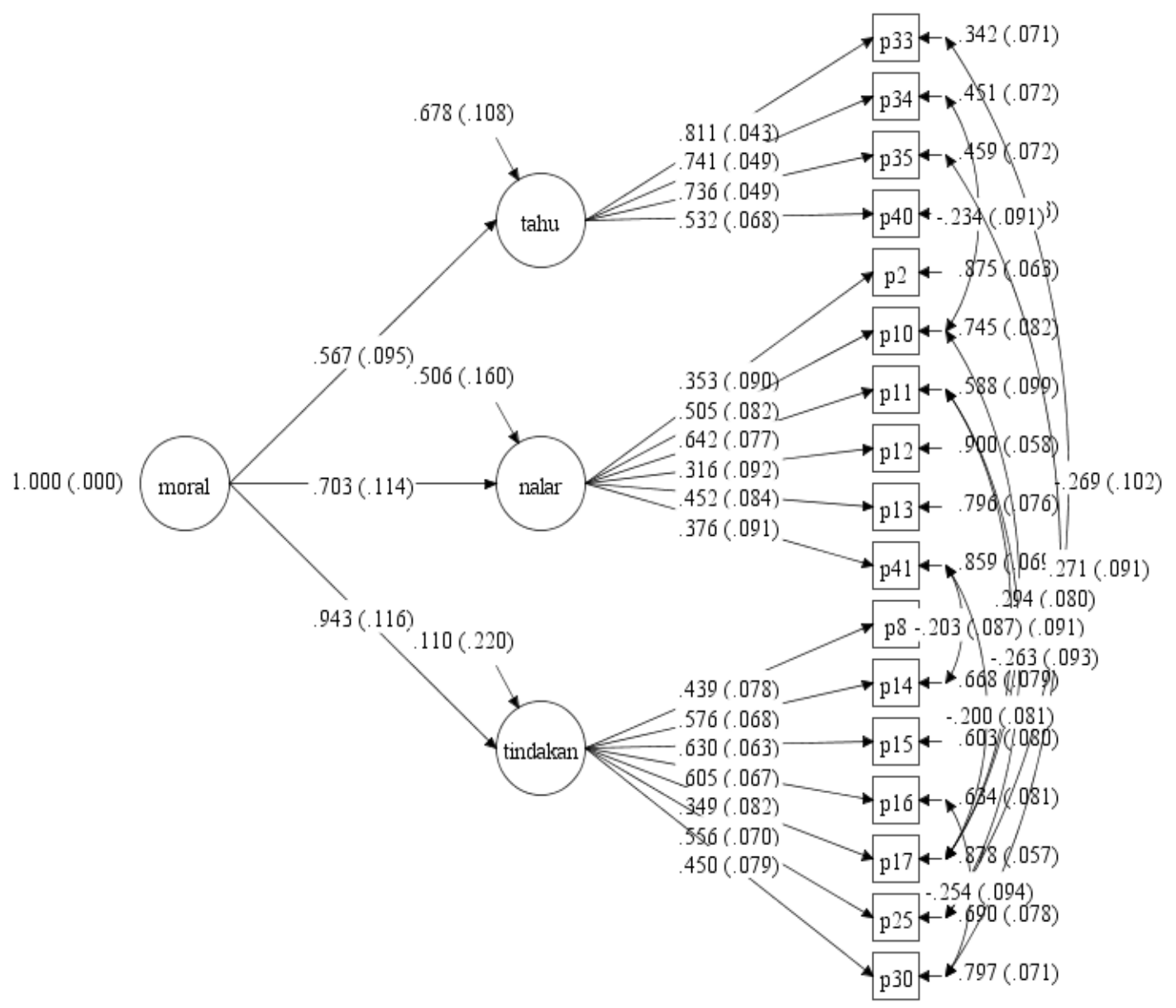

Gambar 4. Hasil CFA Second Order Karakter Moral

Model fit di atas memiliki nilai Chi-Square sebesar 128,672, df = $106(p>0,05)$; RMSEA = 0,038. Namun demikian, beberapa item harus dibebaskan korelasi kesalahan pengukurannya agar dicapai model fit tersebut. Berikut ini penulis laporkan koefisien lambda baik item maupun dimensi pada model CFA second order. 
Tabel 4. Standardized Factor Loading pada CFA Second Order

\begin{tabular}{ccccc}
\hline No Item/Dimensi & Lambda & Std Error & T-Value & $\begin{array}{c}\text { Jumlah Korelasi } \\
\text { Kesalahan } \\
\text { Pengukuran }\end{array}$ \\
\hline P33 & 0,811 & 0,043 & 18,65 & 1 \\
P34 & 0,741 & 0,049 & 15,259 & 1 \\
P35 & 0,736 & 0,049 & 15,093 & 1 \\
P40 & 0,532 & 0,068 & 7,77 & - \\
P2 & 0,353 & 0,09 & 3,945 & - \\
P10 & 0,505 & 0,082 & 6,196 & 2 \\
P11 & 0,642 & 0,077 & 8,359 & - \\
P12 & 0,316 & 0,092 & 3,443 & - \\
P13 & 0,452 & 0,084 & 5,384 & - \\
P41 & 0,376 & 0,091 & 4,13 & - \\
P8 & 0,439 & 0,078 & 5,612 & - \\
P14 & 0,576 & 0,068 & 8,417 & 1 \\
P15 & 0,63 & 0,063 & 9,966 & 1 \\
P16 & 0,605 & 0,067 & 8,992 & 2 \\
P17 & 0,349 & 0,082 & 4,254 & - \\
P25 & 0,556 & 0,07 & 7,975 & - \\
P30 & 0,45 & 0,079 & 5,712 & - \\
Pengetahuan Moral & 0,567 & 0,095 & 5,948 & - \\
Perasaan Moral & 0,703 & 0,114 & 6,186 & - \\
Tindakan Moral & 0,943 & 0,116 & 8,104 & \\
\hline
\end{tabular}

Berdasarkan Tabel 4, diketahui bahwa sejumlah item memiliki korelasi kesalahan pengukuran sekitar 12 kali. Meskipun demikian, item tersebut tidak akan didrop. Sebab memang item-item tersebut adalah hasil dari item yang valid pada tahapan pertama. Disamping itu, wajar apabila terdapat item yang kesalahan pengukurannya berkorelasi dengan item lainnya sekitar 1-2 kali.

Dengan demikian, model CFA second order untuk instrumen karakter moral dinyatakan fit dengan data. Meskipun demikian, terdapat beberapa item yang berguguran dari hasil CFA first order.

\section{Kesimpulan}

Pembentukan karakter moral dan akhlak yang baik pada remaja merupakan pondasi pembangunan manusia secara keseluruhan. Semua orang tua dan masyarakat secara keseluruhan menghargai dan mengakui pentingnya karakter yang baik di antara anak-anak dan remaja. Kekuatan karakter terletak pada bagian inti dari kompetensi moral dan membimbing seseorang untuk menginginkan dan melakukan apa yang layak dan baik. Namun, konsep karakter moral, komponen utamanya, strukturnya, dan perkembangannya masih jauh dari pemahaman. Peneliti mencoba mengembangkan alat ukur pembentukan karakter moral dari teori Ryan dan Lickona (1992), terdiri dari dimensi pengetahuan moral, perasaan moral, dan tindakan moral.

Berdasarkan hasil analisis CFA first order pada tiap dimensi yaitu pengetahuan moral, perasaan moral, dan tindakan moral, didapati model yang fit unidimensi setelah dilakukan modifikasi pada model pengukuran. Dalam hal ini, terpaksa beberapa item digugurkan akibat tidak terpenuhinya asumsi local independence (terjadi korelasi kesalahan pengukuran antaritem). Dari item awal sejumlah 46, item yang tersisa yaitu sejumlah 17 item. Selanjutnya item yang dipertahankan tersebut, dilanjutkan analisis pada tahap berikutnya yaitu CFA second order. Hal ini sejalan dengan penelitian yang dilakukan (Fleeson \& Noftle, 2008) bahwa perilaku yang berbeda bisa terjadi pada orang yang sama (bisa konsisten dan tidak konsisten 
dalam perilaku mereka) artinya bahwa karakter tidak memiliki pengaruh yang besar terhadap perilaku moral atau tindakan moral (Fleeson et al., 2014).

Pada CFA second order, didapati hasil yang fit atau sesuai antara teori dan data, dengan catatan setelah dilakukan beberapa kali modifikasi pada model pengukuran. Pada tahapan kedua ini, didapati semua item signifikan dalam mengukur masing-masing dimensi dan tiap dimensi juga signifikan dalam mengukur konstruk umumnya yaitu karakter moral. Hasil penelitian ini juga sejalan dengan dengan penelitian yang dilakukan oleh (Bazerman \& Gino, 2012) bahwa karakter moral terkait dengan kepribadian.

Berdasarkan hasil CFA first order dan second order secara keseluruhan didapati model fit, namun didapati beberapa item yang saling berkorelasi, sehingga diperlukan penelitian lebih lanjut terkait item-item yang mengukur tentang pengetahuan moral, perasaan moral, dan tindakan moral secara unidimensional.

\section{Daftar Pustaka}

Bazerman, M. H., \& Gino, F. (2012). Behavioral ethics: toward a deeper understanding of moral judgment and dishonesty. Annual Review of Law and Social Science, 8(1), 85-104. https://doi.org/10.1146/annurev-lawsocsci-102811-173815

Cohen, T. R., \& Morse, L. (2014). Moral character: what it is and what it does. Research in Organizational Behavior, 34, 43-61. https://doi.org/10.1016/j.riob.2014.08.003

Fleeson, W., Furr, R. M., Jayawickreme, E., Meindl, P., \& Helzer, E. G. (2014). Character: the prospects for a personality-based perspective on morality: Character. Social and Personality Psychology Compass, 8(4), 178-191. https://doi.org/10.1111/spc3.12094

Fleeson, W., \& Noftle, E. (2008). The end of the person-situation debate: an emerging synthesis in the answer to the consistency question. Social and Personality Psychology Compass, 2(4), 1667-1684. https://doi.org/10.1111/j.1751-9004.2008.00122.x

Holmgren, M. R. (2004). Strength of character. The Journal of Values Inquiry, 38, 393-409.

Joreskog, K. G. And Sorbom, D. (2004). LISREL 8. Scientific softwares international. Chicago.

Koehler, M.D. \& Royer, K.E. 2001. First class character education activities program: ready-to-use lessons \& activities for grades 7-12. NJ: Prentice Hall.

Lickona, T. (2012). Education for character: how our schools can teach respect and responsibility. The Journal of Moral Education.

McAuley, E., \& Shaffer, S. (1993). Affective responses to externally and personally controllable attributions. Basic and Applied Social Psychology, 14(4), 475-485. https://doi.org/10.1207/s15324834basp1404_6

Nucci, L.P., \& Narvaez, D. (2008). Handbook of moral and character education. New York: Routledge.

Park, N., \& Peterson, C. (2006). Moral competence and character strengths among adolescents: The development and validation of the Values in Action Inventory of Strengths for Youth. Journal of Adolescence, 29(6), 891-909. https://doi.org/10.1016/j.adolescence.2006.04.011

Regnerus, M. D. (2003). Linked lives, faith, and behavior: intergenerational religious influence on adolescent delinquency. ournal for the Scientific Study of Religion, Vol. 42, No. 2, 189-203.

Ryan, K. \& Lickona, T. (1992). Character development: the challenge and the model. In character development in schools and beyond. Edited by Kevin Ryan \& Thomas Lickona. Cultural heritage and contemporary change, series VI. Foundations of Moral Education, Vol. 3. Diakses dari www.crvp.org/book/Series06/VI- 3/chapter_i.htm.

Umar, J., \& Nisa, Y.F. (2020). Uji Validitas Konstruk dengan CFA dan Pelaporannya. Jurnal Pengukuran Psikologi \& Pendidikan Indonesia. 